\title{
CHURCH HISTORY
}

\section{Volume 5 1936}

Reprinted with the permission of the original publishet by

Periodicals Service Company

Germantown, NY

2002 
Printed on acid-free paper.

This reprint was reproduced from the best original edition copy available. 


\title{
CHURCH H IS T O R Y
}

\author{
Edited by \\ Matthew Spinka Robert Hastings Nichols \\ Wilhelm Pauck
}

Vol. V

1936

Published by

THE AMERICAN SOCIETY OF CHURCH HISTORY 


\section{THE AMERICAN SOCIETY OF CHURCH HISTORY}

FOUNDED BY PHILIP SCHAFF, 1888: REORGANIZED, 1906: INCORPORATED BY ACT OF THE LEGISLATURE OF NEW YORK, 1916

OFFICERS FOR 1936

WILHELM PAUCK President

Herbert Wallace SchNeIDER Vice-President

ABDEL Ross Weñtz Secretary

ROBERT Hastings Nichols .Treasurer

Matthew Spinka Assistant Secretary

OTHER MEMBERS OF THE COUNCIL

George Warren Richards Winfred ERnest Garrison EdWard Strong Worcester WIILIAM DAVID SCHERMGRHORN WILLIAM WARREN SWEET
Conrad Henry Moehiman FrEDERICK WILLIAM LOETSCHER John Thomas MCNEmL Shirley Jackson Case REUBEN E. E. HaRkNESS

EDITORIAL BOARD OF CHURCH HISTORY

Matrhew SpInKa, Managing Editor

ROBERT HASTINGS NICHOLS

WILHELM PaUCK, ex officio

Publication Office, Berne, Indiana

Executive and Editorial Office, Chicago, Illinois 


\section{TABLE OF CONTENTS}

\section{ARTICLES}

Adair, E. R., Laud and the Church of England

$121-140$

Arpee, Leon, A Century of Armenian Protestantism

Bainton, Roland H., Servetus and Genevan Libertines

Beaver, R. Pierce, The Organization of the Church of Africa .$168-181$

Halperin, S. William, Church and State in Italy during the Last Years of Pius IX

Harkness, R. E. E., Principles Established in Rhode Island .... 216-226

Hooker, Richard James, The Mayhew Controversy 239-255

Holborn, Hajo, The Social Basis of the German Reformation

Knappen, M. M., William Tindale-First English Puritan 330-339

Latta, Maurice C., The Background for the Social Gospel in American Protestantism

Lyttle, Charles, A Sketch of the Theological Development of Harvard University, 1636-1805

$256-270$

301-329

McNeill, John T., Asceticism versus Militarism in the Middle Ages

Moffatt, James, Coverdale

Moore, Dale H., Christianity in Ethiopia

Newcombe, Alfred W., The Appointment and Instruction of S. P. G. Missionaries

Nichols, Robert Hastings, The Plan of Union in New York ....

Petry, Ray C., Calvin's Conception of the "Communio Sanctorum"

Vander Velde, L. G., The Synod of Michigan and Movements for Social Reform, 1834-1869

Weng, Armin George, The Language Problem in the Lutheran Church in Pennsylvania, 1742-1820

\section{Minutes of the Society and List of Menders}

Minutes of the Society and the Council, December, 1935

Minutes of the Spring Meeting, March, 1936

List of Members

\section{In Memoriam}

Daniel Dulany Addison 


\section{BOOK REVIEWS}

Addison, J. T., The Medieval Missionary .................. 400-401

Allen, E. L., Kierkegaard: His Life and Thought ............. 191-192

Arnold, Sir T. W., The Preaching of Islam .................. 185-186

Arnold, W. E., History of Methodism in Kentucky, Vol. I . . . . . . . . . 404

Attwater, Donald, The Catholic Eastern Churches ................ 106

Augustana Historical Society Publications, V ................. 108

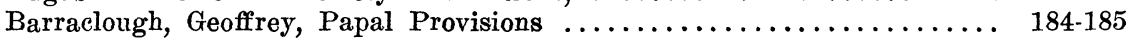

Binns, L. Elliott, Religion in the Victorian Era ............... $392-393$

Bokser, Ben Zion, Pharisaic Judaism in Transition ............... 107-108

Boulter, B. C., Robert Grossetête ..................... 395-396

Braden, Charles S., Varieties of American Religion ............... 292-293

Callahan, Adelbert, Medieval Francis in Modern America .......... 194-195

Castellio, S., Concerning Heretics ...................... 100-102

Coulton, G. G., Five Centuries of Religion, III . . . . . . . . . . . . 287-288

Drury, Clifford M., Henry Harmon Spalding ................. 291-292

Dudden, F. Holmes, The Life and Times of Ambrose, 2 vols. . . . . . . 104-105

Edman, Irwin, The Mind of Paul ........................ 107

Eyre, E., ed., European Civilization, IV, The Reformation . . . . . . . 399-400

Fisher, Allen S., Lutheranism in Bucks County (Pa.) ............. 195

Gray, J. M. M., Prophets of the Soul ...................... 402-403

Hník, F. M., Motives of Benevolence in Christianity ............ 298

Hughes, H. L., The Catholic Revival in Italy, $1815-1915 \ldots \ldots \ldots \ldots \ldots \ldots$. 196-197

Hughes, Philip, A History of the Church, II $\ldots \ldots \ldots \ldots \ldots \ldots \ldots \ldots$ 103-104

Hull, William I., William Penn and the Dutch Quaker Migration to

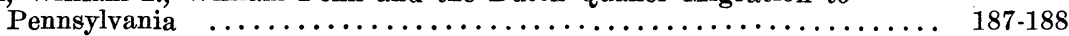

Kiessling, E. C., The Early Sermons of Luther ................ 295-296

Lanning, John T., The Spanish Missions of Georgia .............. 193-194

Levasti, Arrigo, Mistici del Duecento e del Trecento . . . . . . . . . . . 389-390

Lietzmann, Hans, Ecclesia Catholica ........................ 105-106

Macfarland, Charles S., Contemporary Christian Thought ............ 195

Manross, William W., A History of the American Episcopal Church ... 192-193

McNeal, E. T., tr., Robert of Clari's Conquest of Constantinople . . . . . . . . 188-189

More, E. M.-Cross, F. L., Anglicanism .................. 294-295

Morehouse, A. R., Voltaire and Jean Meslier ................. 398-399

Murphy, Du Bose, History of the Protestant Episcopal Church in Texas 195-196

Naef, Henri, Les Origines de la Réforme à Genève . . . . . . . . . . . . . 388-389

Pakenham-Walsh, H., Lights and Shades of Christendom ........... 288-289

Parker, Roberts A., A Yankee Saint .................... 186-187

Pritchard, A., A Short Life of St. Francis ................. 403-404

Raymond, T. W., ed., Orosius' Seven Books against the Pagans ........ 394-395

Reid, W. S., The Church of Scotland in Lower Canada .............. $401-402$

Reu, John M., Quellen zur Geschichte des kirchlichen Unterrichts ....... 98-99

Rodabaugh, James H., Robert Hamilton Bishop ................ 190-191

Ryan, E. O., The Historical Scholarship of Saint Bellarmine ........ 290-291

Schilling, F. A., A Church History Chart .................. 404-405

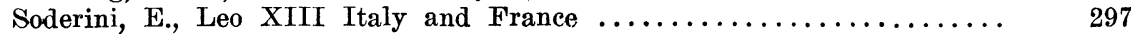

Spinka, Matthew, Christianity Confronts Communism ............ 289-290

Sweet, William W., Men of Zeal ........................ 189-190

Sweet, William W., Religion on the American Frontier:

II, The Presbyterians ........................... 390-391

Sword, V. H., Baptists in Assam ..................... 108-109

Thompson, A. H., ed., Bede ........................ 396-397

Tschan, Francis J., tr., Helmold's Chronicle of the Slavs . . . . . . . . . . 296-297

Williams, W., Saint Bernard of Clairvaux ................ 285-286 


\section{CHURCH HISTORY}

EDITORIAL BOARD

MatTheW SPINKA, Managing Editor

ROBERT HASTINGS NICHOLS

WHHELM PaUCK, ex officio

Vol. V

MARCH, 1936

No. 1

\section{CONTENTS}

Asceticism Versus Militarism in the Middle Ages

John T. McNeill

The Plan of Union in New York

Robert Hastings Nichols

The Synod of Michigan and Movements for

Social ReForm, 1834-1869

L. G. Vander Velde

Church and State in Italy During the

LAST YEARs of PIUs IX

S. William Halperin

Minutes of the Society and the Council,

DECEMBER, 1935

Book Reviews

REU, J. M.: Quellen zur Geschichte des kirchlichen Unterrichts, 9 vols.

Wilhelm Pauck 


\section{CONTENTS}

Bainton, Roland H.: Concerning Heretics...............Wilhelm Pauck Hughes, Philip: A History of the Church,

Vol. II John T. McNeill

Dudden, F. Holmes: The Life and Times of Ambrose,

2 vols. C. C. Richardson

Lietzmann, Hans : Ecclesia Catholica........Conrad Henry Moehlman Atrwater, D.: The Catholic Eastern Churches.........Matthew Spinka Edman, Irwin: The Mind of Paul................................... F. Scott Bokser, B. Z.: Pharisaic Judaism in Transition....Donald W. Riddle Augustana Historical Publications, Vol. V.........B. H. Pershing Sword, VICtor Hugo: Baptists in Assam............Archibald G. Baker 